\title{
AHMET HAMDİ TANPINAR ŞIIIRLERINDE VAROLUŞSAL PROBLEM VE YALNIZLIK
}

\section{THE EXISTENTIAL PROBLEM AND LONELINESS IN THE POEMS OF AHMET HAMDIं TANPINAR}

Ahmet EVIS*

\begin{abstract}
$\ddot{O} z$
Ahmet Hamdi Tanpınar (1901-1962); araştırmacı, şair, yazar ve eleştirmen olarak Türk edebiyatında önemli bir yere sahiptir. Saf şiir yazma arzusuyla sanat anlayışında mükemmelliği arar. Anlamsal kapalılık ve sembollerin yoğunluğundan dolayı eserleri kolaylikla idrak edilebilen türden değildir. Bu nedenle yapılan incelemelerde bazen metin bazen de yazar/şair odakl inceleme metotlara başvurulmuştur.

Bu çalışmayla Tanpınar'ın şair kimliği öne çıkartılarak şiirlerindeki varlık problemine ve buna bağlı yalnızlı̆̆ı ortaya çıkartan hususlara değinilmiştir. Şairin poetik anlayışııın oluşmasında etkili olan edebî şahsiyetlere ve sanat anlayışlarına temas edilerek eserleri anlamlandırılmaya çalışılmıştır. Bunlarla birlikte rüya ve zaman anlayışı odağında şiirlerinde kullandığ̆ imajlarının oluşumuna ve psikanalitik yaklaşımın şiirine yansımalarına da dikkat çekilmiştir.
\end{abstract}

\section{Anahtar Kelimeler}

Ahmet Hamdi Tanpınar, varoluşsal problem, yalnızlık, şiir.

\section{Abstract}

Ahmet Hamdi Tanpinar (1901-1962); as a researcher, poet, writer and critic, he has an important place in Turkish literature. He seeks excellence in understanding of art with the desire to write pure poetry. Due to the semantic closure and the intensity of the symbols, his works are not the kind that can be easily perceived. Therefore, sometimes the text and sometimes the author/poetfocused examination methods were used.

In this work, the problems of existence in his poems and the issues that brought about the loneliness related to it were mentioned while Tanpinar's poet identity was emphasized. His works have been tried to be understood by referring to literary figures and their artistic understandings which are effective in developing Tanpinar's poetical understanding. Furthermore, in the center of dream and time sense, attention also has been drawn to the formation of the images he used and the reflection of the psychoanalytic approach in his poems.

\section{Keywords}

Ahmet Hamdi Tanpınar, existential problem, loneliness, poem.

Arş. Gör. Dr., Mustafa Kemal Üniversitesi, Fen Edebiyat Fakültesi, Türk Dili ve Edebiyatı Bölümü, e-posta: ahmetevis@gmail.com 


\section{GİRIŞ}

Ahmet Hamdi Tanpınar'ın şiirleri, sanat anlayışının anahtarıdır. Tanpınar şiiri, imajların bolluğu, anlamın kapalılı̆̆ı ve dilin kullanılma yöntemiyle özüne ulaşılması zor bir şiirdir. Dolayısıyla şairin poetikası, bu zorluğun aşılmasında en büyük yardımcı olacaktır. Çünkü "poetika, edebiyata dair hem 'soyut' hem de 'içsel' bir yaklaşımdır" (Todorov 2008: 37). Bu doğrultuda incelendiğinde, Tanpınar'ın, poetikasını üç temel unsur üzerine inşa ettiği görülür: Rüya, zaman ve musikî. Ayrıca"felsefilfelsefi arka plan, duygu ve buna bă̆lı olarak sembollerin değişimi, tezatlar ve trajik unsurlar; rüyalardan sonsuzluk âlemine, şuuraltından şuura, iç âlemden dış âleme gidiş; aşk ve ölümün iç içeliği" (Erdoğan 2009: 82) Tanpınar'ın şiirlerinde yer alan belli başlı hususlardır. Tüm bu kavramların çıkış noktasına işaret etmek hem şairin sanat anlayışının hem de şiirlerinin daha açık bir şekilde anlaşılmasına fayda sağlayacaktır.

Ahmet Hamdi Tanpınar şiirleri iki ana kaynaktan beslenir. Bunların ilki Türk dilinin imkânları iken diğeri ise Batı edebiyatı ve daha çok Fransız şiiridir. Tanpınar, Türk edebiyatı içerisinde Yahya Kemal ve Ahmet Haşim'in, Fransız edebiyatında ise Stéphane Mallarmé, Charles Baudelaire, Gérard de Nerval, Paul Verlaine ve Paul Valéry'nin etkisinde kalır. Yazarın poetikasını oluşturmasında pay sahibi olan bu şairlerin edebî anlayışları incelendiğinde hemen hepsinin, nesnelden ziyade soyutu, ideolojik tutumdan çok şahsî düşünceyi merkeze aldıkları görülür. Bir başka ifadeyle şiir anlayışlarının odağında ferdiyetçilik ve sanatsal kaygı vardır. Ahmet Hamdi Tanpınar'daki "mükemmele ulaşma" düşüncesi ve "saf şiir"i yakalama çabası da söz konusu kaygidan kaynaklanır. Ne ki "Tanpınar, 'bakir ve son derece saf şiir'in yazılamaz olduğunu ifade eder. Buna göre saf şiir 'düşüncenin imkânsız bir enstantanesi'dir" (Kolcu, 2009: 50).

Türk şairlerinin Ahmet Hamdi Tanpınar'ın şiiri üzerindeki tesiri incelendiğinde Ahmet Haşim öne çıkar. Zira Tanpınar, Haşim hakkında düşüncelerini belirtirken Türk şiirinin ilk kez onunla çağdaşlarını yakaladığını vurgular: "Biz ilk defa olarak Ahmet Haşim ile Avrupalı mânâsında ve beşeri nispette büyük şiiri tanıdık; şiirin arkasındaki bütün estetik ve nizam âleminin mevcudiyetindeki zarureti öğrendik" (Tanpınar 2007: 295). Haşim'i Türk edebiyatında böylesi önemli bir konuma yerleştiren şair, kullandığı benzer imajları şiirlerinin malzemesine dönüştürür. "Gül, gece, deniz, göl, yıldız, ayna" gibi imajlar, şiirlerine Haşim'den kalan mirastır. Ancak Haşim'in, Tanpınar üzerindeki asıl etkisi daha çok musikîye dayalı bir şiir ortaya çıkartma çabasıyla açıklanabilir. Tanpınar, şairliğinin ilk zamanlarında, Haşim'in şiirlerine çok yakın tarzda yazar. Şairin, bu süreç içerisinde "Hâşim'den aldığı ses ve imajlara yeni bir şey eklediği söylenemez. Sadece dil ve iyimserlik bahsinde Hâşim'den ayrllır" (Kolcu 2002: 99). Kısacası denebilir ki Türk şiiri içerisinde Ahmet Haşim, üslubu ve içeriği yönüyle Tanpınar'ın şiirinin çıkış noktalarından biridir. Tanpınar'ın şiir dünyasını şekillendiren bir diğer şair ise Yahya Kemal'dir. Onun şiirleri ile tanıştıktan sonra Haşim'in etkisini kısmen üzerinden atar. Hocası olan Yahya Kemal'in Türkçeyi kullanmadaki ustalığına hayran kalır ve dil işçiliğine önem verir. Dilde ve şiirin yapısında mısra mükemmelliğine ulaşmaya çabalar. Bergson'dan kanıksayıp şiirlerine taşıdığı süre/durée anlayışına da Yahya Kemal'in ortaya attığı imtidâd ${ }^{1}$ kavramından hareketle ulaşır. Muhteva ya da tematik anlamda ise yine Haşim'in yolundadır:

1 Devam etmek, devam ederek gelişmek manasıyla değerlendirilen imtidâd sözcügüu, Yahya Kemal tarafından Bergson'un süre/durée anlayışına uygun fakat daha milli-manevî çerçevede yorumlanarak kavramlaştırılmıştır. Şimdi, an ve bellek üzerine yoğunlaşan Yahya Kemal; "varoluşsal durumunun yarattı̆̆ algılarla içselleştirdiği şimdiyi, tarihsel boyutuyla değerlendirirken, bellek yardımına sıkça başvurur. Onun bireysel zaman algısını şekillendiren de belleğin bilince taşıdığı hatıralardır" (Deveci 2011: 717). İmtidâd ve durée anlayışını bu biçimde ilişkilendirirken Yahya Kemal, Tanpınar'a göre "kültürümüzün kopan uçlarını birbirine bağlamak suretiyle bize 
“Ahmet Hamdi Tanpınar'ın şiiri bir noktada Yahya Kemal'den ayrılır. Yahya Kemal, aşk ve tabiatla beraber tarihi de şiirine sokmuştur. Tanpınar ise dil ve mısra mükemmelliğini aldığı Yahya Kemal'in tarih görüşünü şiirlerinde değil nesirlerinde gösterecektir. O, şiirlerinde daha çok, gençlik yaşlarında sevdiği Haşim'in izinden yürüyecektir." (Okay 1990: 215).

Tanpınar, poetik anlayışını oluştururken Ahmet Haşim’den aldı̆̆1 musikî ve imaj dünyasıyla Yahya Kemal'den gözlemlediği dili kullanma becerisini harmanlamaya çalışır. Tanpınar'ın "şiirinde zaman teminin, Ahmet Haşim ve Yahya Kemal'den sonra, onların belirlediğ i bir çerçeve içinde, fakat aynı zamanda kendine özgü bir nitelikle yer aldı̆̆ı" (Yuva 2009: 1699) söylenebilir. Tüm bunlar, Tanpınar'ın üslubunun oluşumundaki temel noktalardır. Bunların dişında "içinde bulunduğu edebiyat, sanat, kültür ortamlarının, bizzat kendi zengin iç dünyasının, güzel sanatlara düşkünlüğ̈̈nün, estetik ve mitoloji hocalı̆̆ının, bütün bu alanlarla ilgili yakın arkadaş çevresinin, Fransızca bilgisinin katkısı" (Balcı 2009: 25) şiir dünyasına etki eden diğer önemli faktörlerdir.

Tanpınar'ın peotikasını şekillendiren diğer önemli isimler ise Fransız yazar ve şairlerdir. Keza kendisi de bu durumu ifade etmekten kaçınmaz: "Bende asıl büyük tesir Fransız şiirinden ve bu şiirin Baudelaire-Mallarme-Valery kolundan geliyor" (Kerman 1992: 247). Charles Baudelaire'nin ve Bergson'un zaman görüşünden, Nerval'in rüyaya yaklaşımından, Valéry'nin rüya-bilinç ilişkisinden, Paul Verlaine ile Stephane Mallarme'nin şiirdeki şekil ve üslup anlayışından etkilenir. Tıpkı Ahmet Haşim gibi sembollere önem veren bu şairler, Yahya Kemal'in üslubunu da aratmazlar. Tek ayrım, yerel/millî kültür olarak farklı konumda olmalarıdır. Aslında şiirlerin içeriğine ve onun işleniş tarzına bakıldı̆̆ında, millî olup olmaması da pek önem taşımaz. Çünkü muhteva, daha çok evrensel sembollerle ifade edilen bireye dönük temlerden meydana gelir. Tanpınar'ın, rüyayı merkeze koyması, zamanın bütünlüğüne inanması, var olanla olmayanı ayırt etmeye çalışması imajlarla ifade edilebilecek bir şiir anlayışını ortaya çıkartır. Karakter olarak şahsî yönü ağır basan şairin sanat anlayışının da ferdiyetçilikten uzak duracağı pek ihtimal dâhilinde değildir. Keza Mehmet Kaplan şairin mizacına değinirken "Tanpınar, mizacı, muhayyilesi ve düşünüş tarzı bakımından dağınıklı̆̆a daha meyyaldir" (Kaplan 1982: 189) ifadelerini kullanarak yapılan tespiti doğrular. Ayrıca "gençlik çă̆ında okuduğu Schopenhauer ve Nietzsche, ondaki santimantalizmin kaynă̆ın oluşturur. Daha sonra da psikanalistlere yönelir" (Özer 2006: 91). Etkilenmiş olduğu Schopenhauer, "akıllı adam (...) sözüm ona hemcinsleriyle çok az bir ortak tecrübeyi paylaştıktan sonra, münzeviyane bir hayatı tercih edecektir; hatta eğer büyük bir ruha sahipse büsbütün yalnızlı̆̆ı seçecektir" (Schopenhauer 2005: 11) diyerek Tanpınar'ın kişilik yapısına 1şık tutar. Psikanalistlerden Freud ve Jung'un rüya hakkındaki düşüncelerini incelese de tamamen bunların etkisi altında kaldığı söylenemez. Çünkü Tanpınar'ın rüya anlayışı, kendi sanatı ve estetik düşüncesi etrafında şekillenir.

Sanat eserinin ortaya çıkışında eser-yazar ilişkisinin etkisinden bahsetmek gerekir. Gerek günlüklerindeki yazıları gerekse roman ve hikâyelerindeki kişilerin buhranlı tipler olması, Tanpınar'ın eserlerine yansıyan kişilik yapısını örnekler. Yaşadığı toplum içerisinde hem şahsî hem de kültürel alanda birçok konuda ikilik arasında kalan Tanpınar, belirtilen hususları eserlerine taşıyarak bir anlamda yaşadı̆̆ı sıkıntıları dışa vurur. Buna rağmen roman ve hikâyeleri güdümlü edebiyattan uzaktır. Tanpınar, modernleşme çabası içerisinde gelgitler yaşayan dönemin Türkiye'sinde modern olan, olmaya yaklaşan az sayıda sanat

inkâr ettiğimiz mâziyi, fuzulî bulduğumuz birçok değer hükümlerinin çağdaş ve aslî değerler olduğunu öğretmiştir" (Uçman 2006: 505). İmtidâd anlayışına uygun kaleme alınmış, "diğer şiirlerinden çok farklı bir yapı ve anlam örgüsüne sahip 'Bursa' da Zaman', bir yönüyle Bergson'un durée (kesintisiz zaman) anlayışıyla ilişkili olarak, Tanpınar'ın geçmişte kalan Osmanlı medeniyetini farklı bir bakış açısıyla bugünlere taşıyan yegâne şiiridir' (Uçman 2012: 30). 
adamlarındandır. Ne ki her yeni oluşum gibi modernleşme de beraberinde problemler getirmiştir. "Bütün modernleşmeler trajiktir. Sürekli kendisi olmak ile başkası olmak arasında seçim yapma durumunda kalmak" (Dellaloğlu 2012: 26) modernleşen insanın kaderidir. Tanpınar birçok yönden arada kalışları yaşamıştır. Buna rağmen her daim sanatı ön planda tutarak sıkıntılarını yine bu doğrultuda dile getirmiştir. $\mathrm{O}$, dünyaya estetik kaygıyla yaklaşmış; dolayısıyla "sanatsal ve estetik anlamdaki bir ölümsüzlük peşinde" (Çetin 2002: 44) hayat tüketmiştir. Nükhet Esen, Tanpınar'ın yaşadığı tüm olumsuzluklara rağmen sanat eserlerini oluştururken birey merkezli ve tarafsız bir tutumda olduğundan söz eder: "Bu denli rahatsız, huzursuz ve oldukça mutsuz bir insan olmasına rağmen Tanpınar yine de günlüklerinde sadece kendine odaklı edebî ve estetik kaygılarla yazdıkları üzerine düşünür" (Esen 2012: 103). Şiirlerindeki sanat anlayışı, kaynağını biraz da buradan alır. Konuyu biraz daha detaylandıracak olursak günlüklerine başvurmak gerekir. Tanpınar, günlüklerinde, yaşadığı maddî sıkıntılardan, cinselliğe yaklaşımından, inanç probleminden, Doğu-Batı düalizmi arasında çatışma yaşayan zihniyetten ve en önemlisi kendisinin yine kendisine karşı oluşundan bahseder. Sanat anlayışına şekil veren bu unsurlar, mizacını etkilediği gibi mizacından yansıyan problemler olarak da düşünülebilir. Günlüklerinin bir yerinde kullandığı "geçtiğim yollara bakıyorum. Bütün ömrüm etrafım ve kendim ile mücadele hiç olmazsa kendi kendimi haps ile geçtiğini anlıyorum" (Enginün-Kerman 2010: 294) ifadesi ondaki yalnızlık probleminin çıkış noktasına işaret eder. Ömer Erdem yaptığı değerlendirmeyle Tanpınar'ın yine bu yönüne değinir: "Aslında asıl düalizm şair olmak isteyen Tanpınar ile diğer Tanpınar arasında[dır]" (Erdem 2012: 94). Özetle denebilir ki Tanpınar, poetik anlayışını yaşadığı bunalımlarla estetize edip yalnızlık-varoluş problemine sanatsal kaygıyla yaklaşmış ve eserlerinde tematik bir şekilde işlemiştir.

Düzenli bir poetikası olmamasına rağmen şiir anlayışı üzerine kaleme aldığı "Şiir Hakkında I., Şiir Hakkında II., Şiir ve Rüya I., Şiir ve Rüya II., Şiir ve Dünya Ölçüsü, Şiirin Peşinde" gibi yazıları Edebiyat Üzerine Makaleler adlı kitapta toplanan Ahmet Hamdi Tanpınar, şiir estetiğinin nasıl geliştiği konusundaki bilgileri ise "Kerkük Hatıraları"nda ve "Antalyalı Genç Kıza Mektup"ta açıklar (Özer 2006: 84).

\section{Varoluş Problemi Olarak Zaman, İnsan ve Yalnızlık}

Ahmet Hamdi Tanpınar, şiirlerinde ${ }^{2}$ varlık/varoluş problemini zaman ve rüya ekseninde bazen mekânla somutlaştırarak bazen de sonsuzlukla trajik çerçevede soyutlayarak işler. Tanpınar'ın çoğu şiirinde bir dinginlik, kapalılık, kaçış ya da arayış vardır. Tüm bu etkenler, şairdeki yalnızlık hissinin şiirlerine yansımasına sebep olur. Varlığın özünü aramak, onu, şiir estetiğinin merkezindeki rüyaya yönlendirir. Gerçekliğin ötesine taşan bu anlayış, beraberinde çaresizliği getirir. Çünkü şair, aradığı şeyin gerçekliğinden ya da varlığından dahi emin değildir. Emin olduğu tek husus, varlığın zaman karşısında aciz kaldığı ve tek realitenin zaman/süre olduğudur. Eğer "ân"ın ötesinde zaman varsa varlık/eşya ve mekân da o sayede vardir:

"Ne içindeyim zamanın,

Ne de büsbütün dışında;

Yekpâre, geniş bir ânın

Parçalanmaz akışında" (s. 19).

"Ne İçindeyim Zamanın" şiirinin yukarıdaki dörtlüğü, zamanın varlığına işaret ederken insanın da bu zaman içerisinde anlam kazandığını gösterir. Keza insan, zamanın parçalanmaz

2 Bütün Şiirleri (2011) eserinden yapılacak alıntılarda sadece sayfa numarasına yer verilecektir. 
akışı içerisindedir. Bergson'un durée ${ }^{3}$ anlayışıyla tüm gerçeklik, "an" da değil, parçalanmaz bir bütün olan zamandadır. "Tanpınar'ın özelliği, varlığı her şeyden çok zamana, zamanı da yalnız insana bağlamasındadır. Çünkü yalnız insan zamanın ne içinde ne de büsbütün dışında olabilir" (Eyüboğlu 2002: 146). Özcan'ın belirttiği gibi "varlğ̆ın zamanla münasebetini araştıran Tanpinar, zaman problemiyle karşılaşır ve bu problemi Ne İçindeyim Zamanın şiirinde bütün yönleriyle ortaya koyar. Tanpınar'a göre; insan zamansızdır, çünkü zamanın dışındadır. Insan zamanlıdır, çünkü zamanın içindedir. Bu belirsizliğe ilgili şiirin ilk iki mısraında işaret eden Tanpınar, insan ve zaman fenomenlerinin aykırılığını vurgular. İnsanın zaman karşısındaki konumunu ortaya koymaya çalışan şair, insan ve zaman ilişkisinden abesle çıkar. İnsanın zaman karşısındaki bu aradalığının yol açtığı belirsizlik, üçüncü mısradaki Yekpâre, geniş bir anın / Parçalanmaz akışında ibaresiyle her ne kadar çözülmeye çalışılırsa çalışılsın Tanpınar'ın şiirinde zaman bir problem olmaktan çıkmayacaktır" (Özcan 2012: 77).

Şiirdeki ilgi çekici noktalardan biri ise tasavvuf anlayışı doğrultusunda varlığa yaklaşılmış olmasıdır. Genelde karamsar hatta kimi zaman nihilist denecek düzeyde yaklaşımlara giden Tanpınar, "Ne İçindeyim Zamanın" şiirinde varlığa dinî boyutla bir devinim ve döngü kazandırır. Çoğu kez karamsarlık ve yalnızlıkla sonuçlanan benlik arayışı bu yönüyle "Ne İçindeyim Zamanın" şiirinde farklı bir yapıda görünür. Dikkat edilirse şiirin başında yerini tespit edemeyen hatta varlığını zamanın akışıyla anlayabilen özne/şairin kendisi, şiirin sonunda "muradına ermiş abasız postsuz bir derviş"e dönüşür. Üstelik varlığından şikâyetçi değil bilakis memnundur. Çünkü özne, artık zamanın parçalanmaz akışı içerisinde "masmavi bir ışık ortasında yüzmekte"dir. Bu da tasavvuf ve dinî anlayışın Tanpınar'ın şiir anlayışında yer ettiğinin kanıtıdır. Şiirin tamamında hissedilen dinginlik ve huzur hissi; sükût, rüya, hafif kelimelerinin seçimiyle gerçekleştirilirken mekânın ötesine ve öze ulaşılmışlık hissiyatı mavi, ışık, sarmaşık gibi imajlarla sağlanmıştır. Şiirdeki olumlu atmosfer ve bunun devamlılığı da değirmenin dönüşü ve yüzmek fiilleriyle pekiştirilmiştir.

Zaman-varlık ilişkisinin işlendiği bir diğer şiir ise "Zamanın Kırıntıları"dır. "Ne İçindeyim Zamanın" şiirindeki olumlu atmosfere bu şiirde rastlanmaz. Şair; varlık olarak insanı işlerken onu yine zamana, daha net bir ifade ile "durée/süre"ye bağlı kılar. Şiirdeki "zaman-varlık münasebeti" genel özelliklerine uygun biçimde fakat özne üzerinde olumsuz etkiler doğuracak şekilde işlenir. Zira zaman-varlık ilişkisi, Bergson'un "durée/süre" anlayışına bağlı olarak temellenir; ancak zaman ile durée eş kavramlar değildir. Zaman, durée içerisinde bir parçadır; varlıkla var olur ve onunla kaybolur. Yani ölüm, varlığa son verirken zamanı da öldürür. Ancak durée/süre; devamlılığını korur, kaybolmaz. Tanpınar'ın ifadesiyle parçalanmaz bir akıştır. Söylenenlere uygun olarak, "Zamanın Kırıntıları"nda özne huzursuzdur ve ilk şiirdekinin aksine burada bir murada eriş söz konusu değildir. Şiirde özne olarak insanı seçen şair, varlı̆̆ının zaman içerisindeki aciziyetini "Sessiz kanat çırpanlar / Ve lüzumsuz görenler artık "Biz, zaman kırıntıları / Zaman sinekleri / Tozlu camlarında günlerin/Bu aydınlıkta kendi gölgelerini" (s. 71) mısralarıyla açık şekilde hissettirmektedir. "Daha girişteki 'zaman kırıntıları' ve 'zaman sinekleri' tamlamaları, insanı bir değersizlik hâlinde yakalamaktadır." (Balcı 2008: 57) Sinek sembolü ile

3 Bergson'a göre gerçek zaman, süre (durée) sözcüğü ile ifadesini bulan kesintisiz ve sürekli akışın adıdır (Kolcu, 2002: 186). Yani "Süre'nin özü, akıp gitmektir. Gerçek olan şey, bu akıştır; intikal sürekliliğidir; değişikliğin kendisidir. Bu değiş̧iklik, bölünemezdir" (Bergson 1986: 11). "Zaman rasyonalizmin determinist mantığıyla değil, "l'intution (sezgi)" yoluyla anlaşılabilir" (Aydın 2010: 124). Dolayısıyla sezgi, zamanın ve varlığın mevcudiyetine imkân sağlar. Çünkü "Bergson; sezgiyi, felsefenin yöntemi olarak kabul eder ve bu suretle, mutlak varlığın bilgisinin edinileceği, dolayısıyla, metafiziğin mümkün, hattâ gerekli olduğu sonucuna varır" (Öktem 2000: 172). Ayrıca "bu kavram (durée); bilinçlenme, (varoluşsal bir problem olarak) kendisi olma ve kendini dilediği gibi gerçekleştirme arzusu, (varlğ̆ın gerçekleştirememekten kaynaklanan) kaçma arzusu, (varlık problemlerinin düşürdü̆̈̈̈ çelişkilere karşı) sı̆̆ınma ve aşk / kadın / cinsellik gibi yan temalarla iç içe birbirini doğuran" (Şenderin 2008: 171) bir işleve sahiptir. 
değersizleşen insan, kendisini lüzumsuz görerek tamamıyla sıradanlaşır. Varlığı; artık, bir gölgeden, bir kırıntıdan ibaret kalır. Bu durum, Tanpınar şiirindeki yalnızlık teminin mevcudiyetine örnek olarak gösterilebilir. Çünkü insan, silikleşerek ya da zaman içerisinde bir kırıntı olarak bütünlüğü temsil etmez; aksine yalnızlığa sürüklenir. Şiirin tamamına yansıyan insanın çaresizliği ve yalnızlık duygusu, zamanın imajlarla somutlaştırılmasıyla daha da belirgin hâle getirilir: "Neye yarar hatırlamak / Neye yarar bu cılız ışıklı bahçelerde / Hatırlamak geçmiş şeyleri / Bu beyhude akşam bahçesinde, / Kapanırken üstümüze böyle / Zaman çemberi" (s. 71). Şiirde zaman kavramı, çember olarak somutlaştııılmış ve insanı sıkıştırmaya başlamıştır. Yalnızlıktan kurtulmak için artık hatıralara sığınmak da faydasızdır. Dolayısıyla zaman, insanın varlığına imkân tanısa da kendi varlı̆̆ı altında insanı yine ezerek yalnız bırakır. Şiir içerisindeki "Bu beyhude akşam bahçesi" ifadesiyle hem kronolojik olarak bir "ân"ın hem de mekânın, insanın yalnızlığına çare olamayacağına işaret edilir. Bu çaresizlik ve bütün olarak zaman kavramının üstünlüğüne şiir boyunca vurgu yapılır. Zaman yüceltilirken insanın tek başına varlığı anlamsız gösterilir.

Tanpınar'ın ilk şiirlerinden olan "Musul Akşamları"nın (s. 99-100) geneline sinmiş bir yalnızlık havası hâkimdir. Şairin çocukluğundan izler taşıyan şiirde Ahmet Haşim etkisi görmek mümkündür. Şöyle ki kullanılan kelimelerin seçimi ve sembollere yüklenen anlamlar, Ahmet Haşim'in şiirlerindeki kullanımlarla büyük oranda benzerdir. "Belde, çöl, gece, kızıl..." şiir içerisinde öne çıkan imajlardır. Bunların önemi ise şiirdeki yalnızlık havasını aksettirmeleridir. Yalnızlık hissi, gecenin çöküşüyle daha da belirginleşir. "Karanlık dağılır artık beldeye / Bir esrarl haşyet gezer her evi" diyen şair, gece ile esrarı birlikte vererek şiirdeki puslu atmosferi daha da arttırır. Ayrıca "Nakşeder her huzme ihtiyar şehre / Titrek loş gölgeler, hicranla gamdan..." mısralarındaki şehrin ihtiyarlığı, hicran ve gamın yine şehirle bir arada verilmesi, şiirin baştan sona bu atmosfer içerisinde kalmasına sebep olur.

Tanpınar şiirlerinde ontolojik sorgulama, sadece insan üzerinden yapılmaz. Eşya da mekân da şiirdeki varlık sorununun temel yapı taşlarındandır. Varlığın nasıl var olduğu ya da nasıl farkına varılacağı sorularına idealize edilmiş imajlarla cevap bulunabilir. Zamanın, ölüm ve yalnızlıkla ilişkisi varlıkla beraber işlenirken sonsuzluk kavramı bir arayışla sürekli bir döngü içerisinde vücuda gelmek ister. Bahsi edilen idealize edilmiş imajlar, sonsuzluk arayışı vs. aslında hepsi zamanın tezahürleridir. Örneğin Tanpınar'ın anne sevgisinden yoksun büyümesi onda bir animus kompleksi yaratmış ve bu da bir imaj olarak şiirine yansımıştır:

"Bir günümüz bile sensiz geçmezken

Şimdi mezarma hasretiz anne.

(...)

Kimsesiz bir akşam, ezelden yorgun

Hüznüyle erirken Dicle de sessiz,

Öksüzlük denilen acryla vurgun

Bir başka ölüydük bu toprakta biz" (s. 104).

“Annem İçin"le şair, annesinin kaybından bahseder şiirin başlarında. Ancak sonlara doğru ölüm, annesinden soyutlanarak zamana yansır ve "an" olarak aksettirilen akşam, süre içerisinde eriyerek varlığını yitirir. Öksüz olan öznenin, kendisini ölü olarak tasvir etmesi, varlığın özünün maddede olmadığına işaret eder. Yalnızlığın verdiği melankoli hâli, şiirdeki trajik söylemin ve insanın çıkış noktası olmuştur. Benzer biçimde "Madalyon" şiirinde de annenin yok olmasında zamanın etkisinden bahsetmek mümkündür: 
“Çözülse de vücudun kara toprak altında;

Ihtirasla işlenen bu bir parça altında

Şöhretimle beraber asırlarca yaşarsın" (s. 102).

Buradaki temel vurgu varlığın sonsuzluğa taşınmak istenmesidir. "Asırlarca yaşarsın"dan kasıt, aslında "süre" yani "parçalanmaz akış" ın ebedileştirilmesidir. Kuşkusuz ki bunu en güzel şekilde anne-kadın arketipi sembolleştirecektir. Yukarıdaki mısralar göz önüne alındığında idealaştırılan zaman, öze ulaşmak için maddeden soyutlanarak süreye adanmıştır. Şair, "Zamanın Kırıntıları"nda zamanı, yine bu arketip etrafında somutlaştırarak ilahlaştıracaktır:

"Niçin sen yaratmadın bu dünyayı?

Ellerinin mesut işaretlerinden

Daha güzel doğardı eşya!" (s. 74-75).

Eşyanın mevcut hâlinden ve dolayısıyla varlığından rahatsız olmak, şairi umutsuzluğa sürükler. Zira mevcut olan, ilahenin elinden çok daha güzel vücuda gelecektir. Şiirdeki memnuniyetsiz tutum aslında hem auraya ulaşılamamadan hem de mevcut evren içerisinde yalnız kalınmasından kaynaklanır. Kozmosla bütünleşme çabası içerisinde olan öznenin beklentisini karşılayacak olanın kadın/sevgili/anne olduğu düşünüldüğünde ilahın neden ilaheye dönüştüğü de anlam kazanır. Benzer bir işlevle kadın imajının kusursuz ve idealize edilmiş olduğunu gösteren bir diğer şiir ise "Raks"tır:

"Tilsımlı çocuğu saf aydınlı̆̆ın

Bir kadın vücudu beyaz ve çılak

Eşiğinde sanki sonsuz varlı̆̆ın

Her an değişiyor dönüp uçarak" (s. 58).

Şiirdeki kadın imajı, yine zamanı temsil edecek biçimde estetize edilerek somutlanır. Şairin beyaz ve çıplak bir kadın vücudunu sonsuzluğun eşiğine koyması ve onu sürekli değiştirmesi Bergson'un süre-zaman-an içerisindeki varlığın (sürenin) mevcudiyetine işaret eder. Saf, aydınlık, çocuk ve tılsım kelimelerinin bir arada kullanılması şiirdeki mükemmellik arayışıyla ilişkilendirilebilir. "Her an değişiyor dönüp uçarak" ifadesi ise ilahenin sonsuzluğuna yönelik bir gönderme gibidir. Çünkü sürenin devamlılığı statik duruma ve dolayısıyla bir ilaha/ilaheye uygun düşmez.

Ahmet Hamdi Tanpınar'ın uzun şiirlerinden biri olan "Eşik"te, şair, zaman-varlık ilişkisini eşya üzerinden aktarır ve yalnızlık hissi üzerinde yoğunlaşır. Ayrıca şiirdeki durağanlığın maddeyi/insanı/varlığı rüya hâline yakınlaştırdığı fark edilir:

“Bu yekpare akıs, durgun, derinden...

Her aynada yalniz kendine görünen

Bu yüz ve şifasız hüznü eşyanın

Kendi cevherinde mahpus bir ânın

Dağıttı̆̆g dünya hep yaprak yaprak,

Dalgin, unutulmuş sesleri uzak

Bir uykudan bana tekrar tekrar dönenler,

İçimde, dışımda hep aynı çember!" (s. 63).

Şiirde süreye ulaşmak isteyen fakat zamanda sıkışan bir özne vardır. Özellikle şiirin hemen başındaki "Bu yekpare akış, durgun, derinden" mısrası bu durumu örnekler. Tanpınar'ın zaman 
anlayışı göz önüne alındığında yekpare akışın durgunluğu, şiirdeki trajik söylemin çıkış noktasına işaret eder. Ayrıca "her aynada yalnız kendine görünen / Bu yüz ve şifasız hüznü eşyanın / Kendi cevherinde mahpus bir ânın" mısralarıyla da varlığın zaman içerisindeki yerinden ve çaresizliğinden bahsedilir. Bu da doğal olarak varlığı yalnızlığa sürükler.

Zaman-varlık ilişkisini yansıtan en güzel örneklerden biri "Bursa'da Zaman" şiiridir. "Şair, bir elekten geçirir zaman, bizi bu günlerden alıp yüzyıllar ötesine, tarihin örtüsü altında bir beldeye götürür" (Çongur 2008: 499). Diğer şiirlerinden anlam ve imajlar yönüyle daha açık bir yapıda olan bu şiiriyle Tanpınar, zamanın varlıkla bağını açıkça gözler önüne serer:

"Yeşil türbesini gezdik dün akşam,

Duyduk bir musikî gibi zamandan

Çinilere sinmiş Kur'an sesini

Fetih günlerinin saf neşesini" (s. 51).

Dikkat edilirse şiirdeki özne olan "biz", varlığını yine zamanın içinde fark eder. "Çinilere sinmiş Kur'an sesi"ni zamandan duyan özne, zamanın varlığıyla kendi varlığına anlam verir. Şiir içerisinde geçmişle içinde bulunulan ânın birleşmesi söz konusudur. Yani zaman, geçmiş dahi olsa durağan ya da bitmiş değildir. Sürekli döngü hâlinde ve devam etmektedir. Ayrıca şairin maddenin özüne ulaşmadaki çabası ve bunu başarmanın hazzı da mistik bir atmosferde şiire yansır. Tanpınar'ın estetiğine dair birçok unsuru bünyesinde barındıran şiirde, varlığın zamanla olan ilişkisine musikî ve mimarinin eklenişi de dikkate değerdir. "Dekor ile insan, mekân ile zaman arasındaki birleşmenin, (...) türbenin ve ölümün âdeta ebed̂̂ bir vuslat demi hâline geldiğini görürüz" (Kaplan 2005: 81). Ayrıca şiirdeki müzikalite ve metafiziksel ögeler, varlık probleminin daha da derinleşmesine neden olurken aynı oranda da tespitinin kolaylaşmasını sağlar.

Kısacası Tanpınar şiirlerinde, zaman-varlık ilişkisi çerçevesinde zamanın, yalnızlık doğurarak insanda varoluşsal bir sancıya yol açtığı görülür. An, varlık, kadın, sonsuzluk, akşam, gece gibi imajların kullanılması da yalnızlık duygusunun yoğun olarak hissettirilmesinde etkili olmuştur.

\section{Rüya Estetiği Çerçevesinde Varlık ve Yalnızlık}

Ahmet Hamdi Tanpınar şiirlerinde zamanla birlikte rüya kavramının da varoluş problemine tesir ettiği görülür. Şairin, şiir anlayışının merkezinde olan rüya, işleniş tarzıyla varlıkla yokluk, gerçeklikle metafizik arasındaki bağı kurarak kozmosta sonsuzluğa kapı aralayan bir işleve sahiptir. Şair, rüyalarla bilinçaltına ve bilinçdışına ulaşmayı amaçlar. Rüyanın "zihnin bilinçdışına ulaşan yol" (Brenner 1998: 160) özelliği taşıdığ1 düşüldüğünde Tanpınar'ın şiirinde psikanalitik bir yaklaşımın mevcudiyetinden de söz edilebilir.

Şairin rüya estetiğini açıklarken üzerinde israrla durduğu iki kavram vardır: Rüyaya refakat eden duygu ve rüyayı bilinçli bir şekilde işleme. Şair bu iki hususa mektuplarında açıklık getirir: "Bir rüyaya refakat eden duygu, bir vitrinde teşhir edilen eşyaya verilmiş ışık gibidir. $O$ hayalleri o ışıkta, onun adesesinden, onun aydınlattı̆̆ı kenar ve kabartmalarla, onun aydınlattığı kenar ve kabartmalarla, onun dağıttığı renklerle, kısaca onun kurduğu bir münasebetler zinciri içinde görmeğge mahkûmuz" (Tanpınar 2007: 34).

Burada dikkat çeken nokta, bahsi edilen duygunun aydınlıkla ifade edilmesidir. Nitekim "aydınlık", rüya âlemindeki varlığa anlam kazandırır ve şair bunu yaparken kimi zaman Walter Benjamin'in "aura" 4 anlayışından faydalanır. Eşya ya da özne, çoğu kez ya belirsizlik içerisinde silik olarak ya da yalnızlığı temsil edecek şekilde ortaya çıkar. Bu durum biraz da

4 “Walter Benjamin'in aura adını verdiği kavram bir nesne ya da eseri tarihin, geleneğin, inancın velhasıl geçmiş ve büyük mirasın tuttuğu işıkta görme"dir (Kolcu 2002: 186). 
Valéry'nin rüya anlayışında yer alan arada kalma durumundan kaynaklanır. Ruhsal anlamda bunalımlar yaşayan insan/varlığın kendisini yalnız hissetmesi kaçınılmazdır. Tanpınar'ın bu çatışmaları çok yönlü yaşayan bir sanat adamı olduğu düşünüldüğünde şiirlerinin trajik bir yapıya sahip olması da gayet tabiidir. Ayrıca Schopenhauer'den etkilendiği santimantal hâl, belirtilen trajikliğin ortaya çıkmasında etkili olmuştur. Zira "Schopenhauer, kendi dışındaki bir dünyayla ilişkisini koparmıştır. Dünyaya güvenini tümden kaybedip, âlemle ilişkisini kesince rahatlamıyor insan. Tam aksine daha da bunalıyor ve küçülüyor, daralıyor ve varlığı tahammülü zor bir zindana dönüyor. Çünkü yok edilen haricî âlemin yerini hiçlik, korku ve karanlık dolduruyor" (Özkan 2006: 40).

Ahmet Hamdi Tanpınar'ın, gerçek ve rüya arasında kalmanın belirsizliğini açık şekilde yansitan şiirlerden biri "Her Şey Yerli Yerinde"dir. Şiirin bütününe yansıyan, gerçekle rüya arasında kalmanın ortaya çıkardığı belirsizlik havasıdır. Özne, ne tamamen somut dünyanın ne de rüya âleminin gerçekliği içerisindedir. Bir eşikte bulunan özne, varlığına bu doğrultuda anlam vermeye çalışır. Rüya-eşya düzleminde varlığın reel yönünü, yine aynı şiir içerisinde bulmak mümkündür:

"Belki rüyalarındır bu taze açmış güller

Bu yumuşak aydınlı dalların tepesinde,

Bitmeyen aşk türküsü kumrularm sesinde

Rüyası ömrümüzün çünkü eşyaya siner" (s. 40).

Yukarıdaki dörtlük içerisinde "Bu yumuşak aydınlık dalların tepesinde / Rüyası ömrümüzün çünkü eşyaya siner" mısraları hem eşyanın hem de öznenin varlığını kanıtlar. "Doğadaki varlkkların varoluş nedenini sevgilisine bağh olarak açıklar: 'Belki rüyalarındır bu taze açmış güller' dizesi bunu ortaya koyar" (Asiltürk 2006: 115). Nitekim "yumuşak aydınlı̆̆ı" eşyaya yansımasıyla rüya âlemindeki eşyanın ve öznenin mevcudiyeti dile getirilerek öze ve kozmosa ulaşılmış olur. Asıl gerçekliğin ve özün, görünenin dışında olduğuna inan şair, ömrün eşyada vücuda gelmesiyle bir yerde poetik anlayışını da pratiğe dökmüş olur. Tanpınar; arzuladığı hayatı, kadın imajıyla birleştirerek eşyada gösterir. Zira şairin trajik durumu düşünüldüğünde hayat ve ölümün tezatllğı içerisinde arzulanan tüm durum ve yaşantıların bir ömre sığdırılmak istenmesi de bu açıdan anlam kazanır. Benzer şekilde "Gezinti" şiirindeki "Bir âlem kurulur gibi yeniden/ Baştanbaşa hayâl, düşünce, rüya" (s. 37) misralarıyla hayal, düşünce ve rüya sözcükleri idealize edilerek âlemin varlığına sonsuzluk kazandırılır.

Ahmet Hamdi Tanpınar'ın rüya estetiği bağlamında kullandığı en önemli imajlardan bir diğeri "ayna"dır. Ayna imajı insanın kendi benliğini ve dünyayı yansıtması açısından ontolojik anlamda varlığa imkân sağlar. İmaj olarak ayna, Tanpınar şiirlerinde, gerçeği olduğu gibi yansıtmaz; aksine onun özünü göstermeye çalışır. Şair, şiirlerinde aynanın karşısından değil, daha çok arkasından seyreder evreni. "Nitekim Tanpınar'da bu seyretme durumu kendini

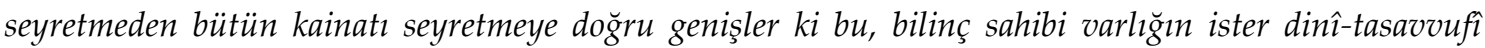
açıdan, ister bilim bakımından olsun, hem kendisini ve hem dış dünyayı ihata etme gayretine denk düşer." ${ }^{5} \mathrm{Bu}$ da onun şiir anlayışındaki "saf"lığın ve özün aranmasıyla alakalıdır. "Sesin" şiirindeki ayna imajı belirtilen yönleriyle kullanılır:

"Sesin yıldızl gecemdir

Başucumda geniş sonsuz

Dalgalanır, derinleşir

5 Balc1, Yunus (2004), Ahmet Hamdi Tanpınar'ın Şiirinde Ayna Üzerine, Erişim Tarihi: 13.09.2009, http://www.yunusbalci.com/mak/25-ahmet-hamdi-tanpjenar8217jen-juiirinde.html 
(...)

Sonra irkilirim birden

Bittiği an bu rüyanın

Geçmiş gibi fark etmeden

Öbür yüzüne aynanın" (s. 35).

Şair, şiirin başında kozmosta var olduğunu "Başucumda geniş sonsuz" mısrasıyla belirtirken şiirin sonlarına doğru aynanın diğer yüzüne geçerek rüyanın bitişinden yani sonsuzluktan tekrar zamana, âna dönüşünden bahseder. Yani varlık, süre içerisinde tekrar tekrar küçülerek yalnızlaşır. İlk mısralardaki olumlu atmosfer, sonlara doğru karamsarlığa dönüşür. Söz konusu dönüşüm, şairin dikkatle seçip kullandığı "irkilirim" kelimesiyle sağlanmıştır. Keza şaire göre insan, sonsuzluktaki rüyadan ancak irkilerek uyanır.

"Ayna" şiirindeki yalnızlık hissi, anlamsal yönden zıtlık gösteren ifadeler ve "su", zaman", "mavi" gibi çeşitli imajlarla sağlanır. Mekân, zaman ve duyuların ağırlıklı olarak tercihi, ayna imajını öne çıkartarak şiirdeki özlem ve yalnız kalma hissinin belirginleşmesini sağlar:

"Hep bu aynadasın artık kış ve yaz

Mavi sularıyla arkanda Boğaz

Köpüren aydinlikta her tepeden,

Hep burada, ömrün her merhalesinde,

Hapsolmuş bir şafak gibi derinde

Zamana gülecek hüznün ve neşen" (s. 45).

Mehmet Kaplan, şiiri değerlendirirken özlenen ve arananın anne figürü olduğuna vurgu yapar. Şairin, aynaya kozmosun arkasından baktığı hatırlandığında, anne-kadın arketipine sonsuzluk katma arzusunda olduğu söylenebilir. Şair, durağan olmayan yekpare bir akış içerisindeki hareketliliği "köpüren aydınlık", "zamana gülecek" ifadeleriyle pekiştirir. Bunlar dışında anne/kadın/sevgili imajına ulaşmak istemesi fakat başaramaması özneyi yalnızlığa sürükler.

"Ey Kartal Bakışlı" şiiri ile Tanpınar, yalnızlık hissini evren içerisinde kaybolmayla ilişkilendirir. Bunu yaparken de yine rüyaya ve ayna imajına başvurur:

"Ey Kartal bakışlı avcısı fecrin,

Açmamış güllerin siyah bahçesi

Büyük hasatçısı serviliklerin,

Varliğın perdeyi yırtan gölgesi;

Ey solgun mâbude, kadehlerimiz

Beyaz aydinlı̆̆a uzanmaz artık,

Aynalar kurıldı mevsimlerle, biz

Strrin gecesinde rüyaya daldı" (s. 53).

Şiir, farklı iki düzlemde incelenebilir. Bunlardan ilki varlığın sembolleştirilerek süre içerisinde öze ulaşması, diğeri ise rüyanın beraberinde getirdiği belirsizlik durumudur. "Aynalar kırıldı mevsimlerle, biz / Sırrın gecesinde rüyaya daldık" mısralarıyla şair, varlığın zaman içerisinde yok olup maddenin öze ulaşmasından bahseder. Realitenin ve maddenin tükenişini ise aynaları kırılmasıyla ve beyaz aydınlığa erişilememeyle vurgular. Şair, "sırrın gecesi" ifadesiyle okuru farklı bir âlem içerisine çeker. Bilinmeyene ulaşmanın çaresini rüyada bulsa da "rüyaya daldık" diyerek rüyayı bir çıkış yolu olmaktan çok, bir belirsizlik durumuna çevirir.

"Deniz" şiirindeki yalnızlık ve özlem temi yine rüya aracılığıyla aktarılır: 
"Çok güzel bir uykudan uyanmış gibi mahmur

Ve hâlâ eşiğinde yarım kalmış rüyanın;

Düşündün, hatırladın, bakışların hülya, nur

Harap kovuklarında yalı rihtımlarmin" (s. 57).

Şiirde açıkça hissedilen özlem, rüyayla yansıtılmış ve dolayısıyla bu özleme son veriş bir çaresizlik doğurmuştur. Çünkü özne, ne uyanıktır ne de rüyadadır. "Ve hâlâ eşiğinde yarım kalmış rüyanın" mısrasıyla şair, rüyanın getirdiği saadetin mevcut zamandaki gerçeklikle örtüşmemesine dikkat çekmiştir. Ânın yahut sürenin içerisinde olmayış, bahsi edilen saadete ulaşamama durumuna temel teşkil etmiştir. Nitekim "Çok güzel bir uykudan uyanmış gibi mahmur" ifadesindeki mahmurluk durumu ise öznenin varlığına anlam verememesine sebep olmuştur.

Daha evvel değinilen "Eşik" şiiri, şairin sanat anlayışını oluşturan ögelerin neredeyse tamamını bünyesinde barındırır. Zaman, rüya, eşya, mekân, öz ve kullanılan imajların çoğu, şiir içerisinde kendine yer bulur. Bu doğrultuda " $E s ̧ i k$ ", varoluşun bir problem olarak görüldügü en belirgin şiirlerin başında gelir:

"Ve bir kadın beyaz, sakin, büyülü

Göğsünde kanayan bir zaman gülü

Mahzun bakışlarla dinler derinde

Olup olmamanin derinliklerinde" (s. 64).

Şiirdeki kadın imgesi ve kanayan gül imajı, zaman içerisinde varlığın sorgulanmasıyla bağdaştırılmıştır. "Olup olmamanın derinliklerinde" diyen şair, açıkça varlık problemine işaret eder ve okuru belirsizlik/rüya hâline sürükler. Kadının imaj olarak kusursuz-ebedî yönü ile kanayan bir gül olarak somutlaştırılan zamanın bir araya getirilmesi, şiirdeki rüya atmosferini yaratmada kullanır. Yine aynı şiirde, eşya-rüya düzleminde şair, mimarî estetiğinden de faydalanir:

"Uzakta, aya çok yakın bir yerde,

Çılgin ve muhteşem harabelerde,

Büyük sükûtların firtınası var" (s. 63).

Şairin güzel sanatlara olan ilgisinin şiirine yansımış hâli olan bu kısımda, varlık somutlaştırılmış ve olumlanarak çizilmiştir. Tanpınar, varlığı idealaştırmış, onun özüne, aurasına, ulaşmaya çalışmıştır. Varlığı uzağa, aya yakın bir yere koymasına rağmen, onu muhteşem sıfatıyla nitelemesi varlı̆̆ın hem mevcudiyetinin hem de biricik olduğunun kanıtıdır. Ne var ki şiirdeki iyimserlik süreklilik göstermez:

"Bütün pinarlara koştum cevap yok

Tekrar bana döndü attı̆̆ım her ok

Her çı̆̆lık önümde tutuştu yandı

Tahtayı kurt oydu, taş yosunlandı,

Yabanî otlarla örtüldü duvar..."(s. 65).

Şiir ilerledikçe özneyi, yalnızlık ve çaresizlik duygusunun kapladığı görülür. Çünkü özne, evren içerisinde ulaşmaya çalıştığı gerçekliğe kavuşamamış ve ümitsizliğe kapılmıştır. Şiir bir bütün olarak incelendiğinde bu kısımda maddenin, öze nazaran daha baskın geldiği göze çarpar. Dolayısıyla özne, süre içerisinde realite ile öz arasında sıkışıp kalmış, bir başka ifadeyle sadece "eşik"te yer bulabilmiştir kendisine. 
Kısaca Tanpınar, rüya estetiğini; çoğunlukla kadın arketipi, zaman ve farklı imajlarla poetik anlayışına büyük oranda sadık kalarak işlemiştir.

\section{Yalnızlık Karşısında Maneviyat, Sonsuzluk ve Ölüm}

Ahmet Hamdi Tanpınar'ın zaman ve rüya estetiği dışında şiirlerinde sıklıkla işlediği diğer kavramlar maneviyat, sonsuzluk ve ölümdür. Bu kavramların şiirlerine tematik yönden yansımaları genellikle yalnızlıkla ilişkilidir. Fanilik ve ölüm, bazen kaçış bazen de teslimiyet hissi oluşturur öznede. Ölüm karşısında çaresiz kalınması, bireyi yalnızlığa sürüklediği gibi maddî/içinde bulunulan evrende yalnız kalma durumu, kimi zaman maneviyatla ödüllendirilir. Bazı eserlerinde maneviyata ve dinî motiflere yer veren şairin, sonsuzluğu ve faniliği zamanla ilişkilendirip Tanrının varlığına işaret etmesi, saf şiir ve mükemmeliyete ulaşma çabasının göstergesidir.

Tanpınar şiirlerindeki ölüm anlayışı, İslamî kültürden de izler taşır. Ancak Tanpınar, ölüm ve ebediyet düşüncelerini tamamıyla İslamî çerçevede kullanmaz. Keza şairin "Allah'a inanıyorum. Fakat tam Müslüman miyım bilemem" (Batur, 1992: 310) ifadesi ondaki ölüm ve ebediyet düşüncesinin niçin bir çatışma şeklinde şiirinde yer aldığının cevabı gibidir. Şair kimliğiyle Tanpınar, ebediyete ulaşmayı sanatsal bir ölümsüzlük olarak tasvir eder. Siyasî kaygılar dışında sanat anlayışına şekil verir. Modernist kimliğiyle dönemin ne sağ ne de sol kanadında yer bulamaması biraz da bundan kaynaklanır. Batı kültürünü iyi bilse de içinde yaşadığı toplumdan kopuk değildir. Ahmet Hamdi Tanpınar, saf şiire ulaşma çabasıyla birçok şiirinde soyuta yönelir ve eserlerinde mistik bir atmosfer yaratır. Mehmet Kaplan, Tanpınar için "mistik olmamakla beraber "ezeli hakikat", "güzellik", "ebediyet ve "mükemmeliyet" $i$ arayışıla mistiklere çok yaklaşır" (Tanpınar, 2011: 11) der. Kimi şiirlerinde belirtilen kavramların İslamî ögelerle birlikte kullanıldığı da dikkatten kaçmaz. "Eşik"teki "Rabbim" ve "Bir Gün İcadiyede"ki "ömür denen uykuya" (s. 52) ifadeleri, İslamî anlayışın şiirinde yer alışına örnek olarak gösterilebilir. Bunların dışında Tanpınar'ın şiirlerindeki kimi imajların İslamî kültür etrafında şekillendiği de göze çarpar.

Kader, fanilik ve ölüm kavramlarının işlendiği şiirlerde dinî motiflerden faydalanılarak bireyin yalnızlıktan sonsuzluğa ulaşması söz konusudur. Bu sonsuzluk, kimi zaman süre ile kimi zaman da maddî dünyanın dışında kalmakla idealize edilir. "Şiir"deki kader ve ebediyet anlayışı, belirtilen hususlar etrafında işlenir:

"İçimizde sonsuz çalkanan deniz,

Gülümseyen yüzü kaderin bize,

Yildızların altın bahçesindeyiz,

Ebediyetinle geldik diz dize" (s. 24).

Şiirdeki ebediyet, süreye tekabül ederken "kaderin gülümseyen yüzü"nün ebediyete ulaşmada bir araç olarak kullanıldığı görülür. "Yıldızların altın bahçesi", "sonsuz çalkalanan deniz" ifadeleri, sürenin bütünlüğünü belirtilmede özellikle tercih edildiğini düşündürür. Bunlarla birlikte ölümü çağrıştıran "kaderin gülümseyen yüzü" söylemi ise ebediyete ulaşma çabasıyla ilişkilidir. Genellikle olumlu bir atmosferde devam eden şiirde, şairin; deniz, yıldız, altın gibi imajların kullanması bu doğrultuda anlamlıdır.

"Selam Olsun", öteki âlemin varlığı ve yalnızlık hususunun mevzu bahis edildiği bir başka şiirdir:

"Selam olsun bizden güzel dünyaya,

Bahçelerde hala güller açar mı? 


\section{(...)}

Uzak, çok uzağız şimdi ışıktan,

Çocuk sesinden, gül ve sarmaşıktan.

Dönmeyen gemiler olduk açıtan,

Adınızı soran, arayan var mı?" (s. 28).

Anlaşıldığı üzere özne, maddî dünyaya bir başka boyuttan seslenmektedir. "Güzel dünya" diyen özne, içindeki özlemi dışa vurur. Bu noktada yalnızlıktan söz etmek de mümkün olur. Çünkü öznenin, içinde bulunduğu mistik boyuttan seslenerek maddî evreninin ögelerini anması, eskiye hasret duyduğunu gösterir. Benzer şekilde maddî evrenin, olumlu imajlarla estetize edilmesi bu durumun bir diğer göstergesidir. "Siyah Atlar" şiirinde ise ölüm ve kaçışın izine rastlanır. "Bir gün kapatırsın bu ufukları / Beklersin köşende sessiz ve yorgun / Siyah atların son yolculuğun" (s. 30) misralarıyla sembolleşen ölüme gidiş, şiirin sonunda öznenin ölümün çemberinden kurtulmasıyla son bulur. Şiirin tamamında ise bir yalnızlık havası ve ölümün soğuk yüzüne vurgu vardır. Ayrıca imaj olarak "at"ın seçilmesi, hız ve hareketle bağlantılıdır. Yani ölüme gidiş hızlı şekilde gerçekleşecek ve özne arzuladığı uzun hayatı yaşayamayacaktır. Burada vurgulanması gereken esas husus, Tanpınar'ın şiirlerinin salt yalnızlık hissinden ibaret olmadığıdır. Zira Tanpınar, yaşama arzusunu öne çıkartarak sadece varoluşçu akımın veya modernizmin içe kapanık yönünün etkisinde kalmadan şiirlerine özgünlük kazandırabilmiştir.

Ahmet Hamdi Tanpınar'ın mimari estetiği ile şekillenen ve eşyayla ilişkilendirilerek sonsuzluğa ulaşılmış olmanın ifade edildiği "Bir Heykel İçin" şiiri, şairin poetik anlayışındaki birçok ögeyi bir arada bulundurması yönüyle dikkate değerdir:

"Tahtadan ve yumuşak rüya iş̧̧iliğinde

Bu kadın başı her an biraz daha derinde,

Daha hülyal, dalgin, ümitsizce kendisi

Toplanmış ay ışı̆̆ı, yüzen tek su nergisi

(...)

Gülümsüyor ölümün sonsuzluğu içinden

Gülümsüyor vaktiyle nasıl gülümsediyse

Ömrünün sabahında ümide ve sevgiye" (s. 31).

Kadın, heykelle estetize edilen zaman ve mükemmeliyet ögeleri, "Gülümsüyor ölümün sonsuzluğu içinden" mısrasıyla öne çıkartılarak ölüm aracılığıyla ebediyete ulaştırılır. Şair, aura anlayışıyla eşyanın özüne erişme çabasındadır. Keza şair, aura ile heykel olan kadın başını durée/süre içerisinde gösterir. Bunu yaparken de "Bu kadın başı her an biraz daha derinde / Ömrünün sabahında ümide ve sevgiye / Gülümsüyor ölümün sonsuzluğu içinden" mısralarındaki zaman ögelerinden faydalanır.

Ahmet Hamdi Tanpınar'ın Yahya Kemal' in "Sessiz Gemi"sini andıran şiiri "Rıhtımda Uyuyan Gemi"de ölüm ve öteki âleme işaret eden birçok ifade yer alır:

"Nolur bir sabah saati

Çă̆ırsa bizi sonsuzluk,

Birden demir alsa gemi

Başlasa güzel yolculuk.

(...)

Rihtımda uyuyan gemi

Hatırladin me engini

Gidip de gelmeyenleri 
Beyhude bekleyenleri..." (s. 39).

Ölüme gidiş "gemi” imajı ile işlenirken öteki âlem, sonsuzlukla sembolleştirilir. Yalnızlık ve yalnızlık karşısında ölüme sığınış "Nolur bir sabah saati / Çağırsa bizi sonsuzluk" mısralarıyla ifade edilirken ölümün, varlığı maneviyata taşıyan işlevi örneklenmiş olur. Ayrıca şair, "Başlasa güzel yolculuk" mısrasındaki yolculuk olarak gösterdiği ölümü güzel sıfatıyla nitelemesi ise tamamıla ölüme duyulan özlemle alakalıdır. Bunların haricinde "Gidip de gelmeyenler", "Beyhude bekleyenler" ve "Birden demir alsa gemi" ifadelerinde İslamî düşüncenin ve kader anlayışının varlığından da söz etmek mümkündür.

"Dönüş" şiirinde, yalnızlık ve ölümün yansımaları iç içe işlenerek ontik mânâda karamsar bir tablo çizilir:

"Bir akşamın beyaz fecre

Gönderdiği kanlı haber,

Herkes ömründe bir kere

Bu zalim dönüşle titrer" (s. 54).

Şairin "Herkes ömründe bir kere / Bu zalim dönüşle titrer" misralarında vurguladı̆̆ zalim dönüş, ölümün kendisidir. "Titrer" sözcüğü ile ölüm karşısında bireyin içindeki korku vurgulanır. Ayrıca ölüme ve yalnızlığa karşı takınılan olumsuz tavır, yine aynı şiir içerisindeki "Rüya dolu uykusunu / Güllerin üzüntüsünde" misralarında da görülür.

"Altın Güzeldir" şiiriyle şair, öznenin evren karşısındaki yalnızlığına değinir:

"Sen son rüyalarm aynasinda

Beyhude ararken kendini

Tek bir filizden çoğalır dünya..." (s. 82)

Şair, öznenin benlik arayışını anlamsız bularak onu evren karşısında yalnızlığa sürükler. Bunu yaparken de "Beyhude ararken kendini" misrasına başvurur. Şiirin sonunda "Ve sesinin her gurbeti / Benimseyen hatırasında" (s. 82). diyerek yine öznenin yalnızlık duygusuna kapıldığına işaret eder. Ayrıca şair, rüya anlayışı içerisinde ayna imajını kullanarak yalnızlık ve çaresizlik hissini pekiştirir. Ne ki şiirdeki yalnızlık durumu devamlı değildir. Bireyin acizliği karşısında dünyanın filizlenerek çoğalması öznenin acizliği karşısında evrenin büyüklüğüne sığınmayla çözüme kavuşturulur. Şair, kozmostaki döngüyü ve zamanın bütünlüğünü tabiat unsurlarıyla birleştirerek metafiziksel bir hava ortaya çıkartır.

Fanilik ve ölüm karşısında bireyin yalnızlığı temine "Annem Iç̧in" şiirinde de değinilir:

"Issiz bir mezarlik, kimsesiz bir yer

Gölgesinde ulu, loş bir mâbedin

Bir yı̆̆ın toprakla bir parça mermer

Strrıla haşr olmuş orda ebedin.

Bir yığın toprakla bir parça mermer,

Üstünde yazılı yaşınla, adın;

Baş ucunda matem renkli serviler

Hüznüyle titreşir sanki hayatın" (s. 104).

Şiire yansıyan özlem ve çaresizlik, "Bir yı̆̆ın toprakla bir parça mermer" söylemiyle, ölüm/sonsuzluk ise "ebedin" sözcügüule bütünleştirilir. Mezar, toprak; faniliği ve yok oluşu çağrıştırırken sır ve ebediyet karşısında öznenin bunalıma düşmesi ise insandaki trajik durumun meydana çıkmasına sebep olur. Ayrıca şiirdeki ilahi yapı, şiirin başından sonuna 
kadar varlığını hissettirir. Yaşamı temsil eden servilerin matem renkli oluşu ve titreşir sözcüğü, şiirde huzursuzluk havası yaratır. Bu olumsuz atmosferin odağında, annesizlikten ve fani olmaktan kaynaklanan yalnızlık vardır. Benzer biçimde kadın imajının kusursuzluğuna şiirlerinde sıkça yer veren Tanpınar'ın "Annem İçin" şiirinde ölümle kadını bir araya koyması yine bu açıdan dikkate değerdir.

Ölüm korkusu bağlamında değinilmesi gereken bir diğer şiir ise "Odalarda Akşam"dır:

“Bu akşam düşünen gözlerin yine,

Mehtapla hareli karanlik bir su...

Daldıkça alıyor derinliğine,

Ruhumu bir sonsuz ölüm korkusu

(...)

Bir ölümün kalbe sinen gamıyla

Bak ürpermedesin, titriyor sesin,

Soldukça biten kış akşamıyla

Fersiz aynalarda anbean aksin" (s. 107).

Özne, ölümün karanlık yüzüne ve dolayısıyla ölüm korkusuna kapıldığını “Daldıkça alıyor derinliğine / Ruhumu bir sonsuz ölüm korkusu" mısralarıyla açıkça dile getirir. Ölüm karşısında yalnızlaşan bireyin zaman unsurlarıyla karşı karşıya getirilmesi, aynanın fersizleşmesi, şiirdeki hüznün ve çaresizliğin hissettirilmesinde kullanılır. "Bir ölümün kalbe sinen gamıla" mısrasındaki anlamın açıklığı ise ölüme nasıl bakıldığı sorusunun cevabını vermekte yeterlidir. Şiirdeki mekânın kapalı mekân şeklinde tercih edilmesi ayrıyeten dikkat çekicidir. Odanın, durağan yapısıyla korku ve huzursuzluk hissiyatını yansıtmak için özellikle seçilmiş olması kuvvetle muhtemeldir.

"Bir Yolcuya" şiirinde bireyin yalnızlığının ve yalnızlık karşısında değer kazanmasının en büyük etkenleri -millî değerlere bağlı olarak- sonsuzluk, ölüm ve özlem hissi olarak gösterilir:

"Kalbin hürmetle çarpsin bu mezarın yanında!

Bil ki bu şehitlere ebediyet baş eğer,

Ölüm çiçek açmıştı bu gençlerin kanında

Zafer bir hâledir ki kemiklerini bekler" (s. 110).

Şiirdeki manevî yapı; fanilik-ebediyet, mezar-yükseliş gibi zıtlıklarla öne çıkartılır. Kadın imajıyla idealize edilen maneviyata; şehit, zafer, çiçek, ebediyetin baş eğişi gibi sözcüklerin yakıştırılmasıyla daha da kıymet kazandırılır. Yani gerçek varoluşun değerler uğrunda yok oluştan geçtiğine vurgu yapılması, şiirin tamamına maneviyattan kaynaklanan bir huzur havasının sinmesini sağlar. Bu şiiri farklı kılan noktalardan bir diğeri ise şiirin içerisinde tarihî ögelere rastlanmasıdır. Tanpınar'ın tarih, kahramanlık, millî kültür gibi unsurlara şiirlerinde pek yer vermediği düşünüldügünde "Bir Yolcuya" şiiri daha da önem kazanır.

"Ölü"de özne, ölüm hâlinden yaşama seslenir. Faniliği hemen her yönüyle yaşamışsa da ölümün kaçınılmazlığını somut dünyadaki bireye hatırlatır:

"Kabrimi gösteren taş parçasından

Yillarla silinmiş olsa da adım

Bir zaman, ey yolcu, bende yaşadım.

Çılgın heveslerim vardı benim de,

(...)

Ve bir avuç toprak oldum en sonu" (s. 113). 
Fani insanın ihtiraslarına, yaşantılarına değinen özne, "yolcu"yu ölüm hâlini hatırlatmak için bir aracı olarak kullanır. "Ve bir avuç toprak oldum en sonu" mısrasıyla ölümün kaçınılmazlığını dinî tasavvurla esere yansıtır. Keza öznenin, ihtirasları, kırılmaz bir taç olarak gördügü bahtı, şen veya kavgacı hâlleri mezarda son bulmuştur. Ve nihayetinde dediği gibi toprak olmuştur hayatının son bulmasıyla. Yani fanilik, özneyi çaresiz bırakmıştır. Şairin poetik anlayışına uygun olarak zaman-varoluş ilişkisinin de şiirde yer aldığı dikkatten kaçmaz. Zaman, öznenin varlığına imkân sunarken ölüm, zamanın tükenişiyle ilişkilendirilip yok oluşa sebep olur.

"Sen ve Ben" şiirinde faniliğe değinen şair, kendisiyle bir başkasını mukayese ederek gençlik-ihtiyarlık zıtlığını tematik bir şekilde esere yansıtır:

"Sen, yirmi yaşında bir baharsın ki,

Gölgende neşenin rüzgârl eser.

Düşünen alnımda benim her çizgi

Baharı olmayan bir kışa benzer.

Sana ufuklar "Gel!" diye bağırır,

Ellerinde çiçek haykırarak;

Seni gür sesiyle hayat çağırıı,

Beni de çiğneyip geçtiğin toprak" (s. 117).

Şiir, Tanpınar'daki trajik durumun birebir yansıması olarak değerlendirilebilir. Şair, ölüme bakışı ve varlık problemine yaklaşımını, "Sen ve Ben" şiirine açık şekilde yansıtır. Özne, ihtiyarlıkla ölüme yakındır. "Sen" dediği ise gençliğiyle hayatının baharını yaşamaktadır. Özne, gençlikle alnındaki çizgileri, bahar ile kış unsurlarını bir çatışma unsuru olarak hisseder ve ölüme yakınlık derecesini hatırlayarak yalnızlık duygusuna kapılır. En azından gençliğin karşısında yaşlılığın ölüme yakın oluşu, şiir içerisinde rahatsızlık duyulan bir durum olarak sezdirilir.

\section{SONUÇ}

Ahmet Hamdi Tanpınar, poetik anlayışının temel yapı taşlarından olan rüya ve zamanı kullanarak saf şiire ulaşmayı amaçlar. Bu doğrultuda durée/süre ve aura anlayışına sıklıkla başvurur. Çünkü şair, mükemmelliği/saf şiiri belirtilen kavramlar etrafında şekillendirmeyi arzular. Bunların yanında musikî ve mimarinin de Tanpınar'ın şiir estetiği içerisinde önemli bir yere sahip olduğu gözlemlenir. Ayrıca Ahmet Haşim, Yahya Kemal ve dönemin sosyoekonomik çalkantılarından etkilenen Tanpınar'ın, şiirlerinde yalnızlık ve çaresizlik durumunun belirmesi de kaçınılmaz olur. Sanat adamı olmasının yanında insanî yönüyle hassas bir yapıda olması, Ahmet Hamdi'nin eserlerindeki trajik söylemin ortaya çıkmasında pay sahibidir.

Varoluşçuluk akımını, modernist sanat anlayışını ve Doğu-Batı sentezini içselleştirmiş olan şair, psikanalitik metodu kullanarak bireyi çok yönlü olarak eserlerine taşır. Yarattığı bireyi, çeşitli tezatlar etrafında çoğu kez ikileme düşürerek şiirdeki yalnızlık ve içe kapanıklığı dikkat çekici oranda belirginleştirir. Şairin bu tutumu kuşkusuz ki ileriki dönemlerde Türk şiirinde önemli yer tutacak olan İkinci Yeniciler üzerinde yapıcı etkiler ortaya çıkarır.

Varlık ve yalnızlık probleminin işlendiği Ahmet Hamdi Tanpınar şiirlerinde çatışmaların mevcudiyeti açıkça görülür. Varlık ile yokluk arasında bunalımlar yaşayan insanın, zamanın ötesine ulaşma arzusuyla kendini araması, genellikle sembollerle ifade edilir. Varoluşun eşya ve mekânla ilişkisini rüya hâlindeki bireyle ilişkilendiren Tanpınar, onu zamanın ötesine taşımaya çalışır. Bunu bazen yaşam karşısında ölümü tercih ederek bazen anne-kadın imajını estetize 
ederek bazen de zaman ve ânı somutlaştırarak gerçekleştirir. Kimi şiirlerinde ölüm, fanilik ve manevî yapının bireyin yalnızlığına çeşitli yönlerden etki ettiği görülürken çok sık olmamakla beraber İslamî ögelerin izlerine de rastlanır. Din, Tanrı ve ölüm kavramalarının sonsuzlukla bağının ve öteki âlemin söz konusu olduğu şiirlerinde ise mistik bir atmosferin varlığından da bahsetmek mümkündür.

Kusursuz şiiri kovalayan Ahmet Hamdi Tanpınar'ın zaman, rüya ve musikî dışında mimari ve mitolojik ögelerden faydalandığı görülür. Şair, yeni imajlarla estetize ettiği şiirlerini çok katmanlı bir düzleme oturtarak varoluş ve yalnızlığın anlamlandırılmasında okura sınırsız özgürlük tanır. Modernist kimliğiyle Yahya Kemal, Ahmet Haşim ve Fransız şairlerinin izlerini taşıyan Tanpınar şiiri, kendi dönemi içerisinde farklı ve önemli bir yerdedir. Döneminin felsefî ve edebî akımlarından yararlanan Tanpınar, bu akımların salt kurallarına bağlı kalmadan Doğu ve Batı kültürünü harmanlamayı başarır. Ancak onun sanat anlayışı gereği şiirleri, tematik veya muhteva yönüyle hiçbir zaman bu iki medeniyete ait ögelerle sınırlı kalmaz. Milli değerleri imtidâd bağlamında evrensel değerlerle ilişkilendirerek orijinal bir sanat anlayışı geliştirmiştir.

Özetle; Tanpınar, modernizmin öznelliği ile mistik atmosferi birey, zaman, rüya, musikî, tarih, mimari özelinde işlemesini bilmiştir. Kuşkusuz ki bu da Tanpınar'ın derin bilgi birikiminden ve sanatkâr kimliğinin çok yönlü olmasından kaynaklanır. 


\section{KAYNAKÇA}

ASILTÜRK, Baki (2006), Parçacllılıktan Bütünselliğe Bir İdealar Tablosu: Her Şey Yerli Yerinde”, ToplumBilim "Ahmet Hamdi Tanpinar Özel Sayısı" (20): 113-117.

AYDIN, Mehmet (2010), “Kayıp Zamanın İzinde” Ahmet Hamdi Tanpınar, İstanbul: Doğu Batı Yayınları.

BALCI, Yunus (2004), Ahmet Hamdi Tanpınar'ın Şiirinde Ayna Üzerine, Erişim Tarihi: 13.09.2009, http://www.yunusbalci.com/mak/25-ahmet-hamdi-tanpjenar8217jen-juiirinde.html

BALCI, Yunus (2008), Tanpınar -Trajik Bir Şair ve Şiir-, İstanbul:. 3F Yayınevi

BALCI, Yunus (2009), Bir Sanatkârın Bilim Adamı Olarak Portresi: Ahmet Hamdi Tanpınar, Turkish Studies C IV (1): 5-28.

BATUR, Enis (1992), Ahmet Hamdi Tanpınar'dan "Seçmeler", İstanbul: Yapı Kredi Yayınları.

BERGSON, Henri (1986), Düşünce ve Devingen, İstanbul: MEB Yayınları.

BRENNER, Charles (1998), Psikanaliz / Temel Metinler, Ankara: HYB Yayıncilik.

ÇETIN, Nurullah (2002), "Ahmet Hamdi Tanpınar'ın Şiiri”, Hece Dergisi, Ahmet Hamdi Tanpınar Özel Sayısı, (61): 39-57.

ÇONGUR, H. Rıdvan (2008), Ahmet Hamdi Tanpınar ve Zamanı Yaşamak, Türk Dili, C XCV, (678): 499-503.

DELLALOĞLU, F. Besim (2012), Ahmet Hamdi Tanpınar -Modernleşmenin Zihniyet Dünyası Bir Tanpınar Fetişizmi-, İstanbul: Kapı Yayınları.

DEVECI, Mutlu (2011), "Yahya Kemal'in Süleymaniye'de Bayram Sabahı Şiirinde Zamana Diyalektik Bir Bakış", Turkish Studies, C VI (3): 715-729.

ENGİNÜN, İnci - KERMAN Zeynep (2010), Günlüklerin Işı̆̆ında Tanpınar'la Başbaşa, İstanbul: Dergâh Yayınları.

ERDEM, Ömer (2012), Şair Olan Tanpınar ya da Şiirinde Olmayan Tanpınar, Ahmet Hamdi Tanpınar -Tanpınar Zamanı Son Bakışlar-, s. 94-99, İstanbul: Kapı Yayınları.

ERDOĞAN, Mehmet (2009), Bir Eleştirmen Olarak Ahmet Hamdi Tanpınar, İstanbul: Dergâh Yayınları.

ESEN, Nükhet (2012), "Günlüklerdeki Tanpınar", Ahmet Hamdi Tanpınar -Tanpınar Zamanı Son Bakışlar-, s. 100-106, İstanbul: Kapı Yayınları.

EYÜBOĞLU, Sabahattin (2002), "Tanpınar'da Zaman", Bir Gül Bu Karanliklarda, İstanbul: Kitabevi Yayınları.

KAPLAN, Mehmet (1982), Tanpınar'ın Şiir Dünyası, İstanbul: Dergâh Yayınları.

KAPLAN, Mehmet (2005), Şiir Tahlilleri 2 -Cumhuriyet Devri Türk Şiiri-, İstanbul: Dergâh Yayınları.

KERMAN, Zeynep (1992), Tanpinar'ın Mektupları, İstanbul: Dergâh Yayınları.

KOLCU, Ali İhsan (2002), Zamana Düşen Çığlık: Tanpınar'ın Şiirinin Epistemolojik Kaynakları, İstanbul: Dergâh Yayınları.

KOLCU, Ali İhsan (2009), Tanpınar'ın Poetikası, Erzurum: Salkımsöğüt Yayınları.

OKAY, Orhan (1990), “Ölümünün Yirmi Beşinci Yılında Ahmet Hamdi Tanpınar: Hayatın Batısından, Şiirin Doğusuna", Sanat ve Edebiyat Yazıları, s. 204-218, İstanbul: Dergâh Yayınları.

ÖKTEM, Ülker (2000), "Descartes, Kant, Bergson ve Husserl'de Sezgi", A.Ü. DTCF Dergisi, C XL (1-2): 159-189.

ÖZCAN, Tarık (2012), “Tanpınar'ın Şiirlerinde Zaman Anlayısıı”, Fırat Üniversitesi Sosyal Bilimler Dergisi, C XXII (1): 75-84.

ÖZER, E. Emine (2006), “Tanpınar'ın Şiir Anlayışı ve Şiirinin Kaynakları Üzerine Bir İnceleme”, Pamukkale Eğitim Fakültesi Dergisi, (20): 83-91.

ÖZKAN, Senail (2006), Schopenhauer Paradaokslar Üzerinde Raks, İstanbul: Ötüken Neşriyat.

SCHOPENHAUER, Arthur (2005), Okumak-Yazmak ve Yaşamak Üzerine, İstanbul: Şule Yayınları.

ŞENDERIN, Zübeyde (2008), “Ahmet Hamdi Tanpınar’ın Hikâyelerinde Karakter Yaratımında Çocukluk Yıllarının Rolü", Gazi Türkiyat, (2): 169-184.

TANPINAR, Ahmet Hamdi (2007), Edebiyat Üzerine Makaleler, İstanbul: Dergâh Yayınları.

TANPINAR, Ahmet Hamdi (2011), Bütün Şiirleri, İstanbul: Dergâh Yayınları.

TODOROV, Tzvetan (2008), Poetikaya Giriş, İstanbul: Metis Yayınları.

UÇMAN, Abdullah (2006), “Değişen Değerler Karşısında Ahmet Hamdi Tanpınar”, Türkiye Araştırmaları Literatür Dergisi, C IV (7): 479-509.

UÇMAN, Abdullah (2012), “Ölümünün 50. yılında Ahmet Hamdi Tanpınar'1 Hatırlamak”, TYB Akademi Dil Edebiyat ve Sosyal Bilimler Dergisi, C II (5): 21-37.

YUVA, Hümeyra (2009), “Türk Şiirinde Zaman Teminin Değişimi”, Turkish Studies, (4): 1653-1717. 